\title{
Vertical eddy diffusivity in the subsurface pycnocline across the Pacific
}

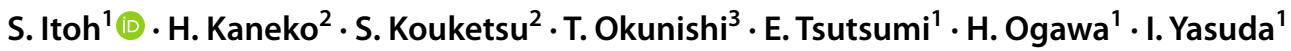

Received: 2 August 2020 / Revised: 1 December 2020 / Accepted: 20 December 2020 / Published online: 9 January 2021

(c) The Author(s) 2021

\begin{abstract}
In the stratified ocean, vertical eddy diffusivity in the subsurface pycnocline plays a major role in new production through transporting nutrients upwards from the darker/nutrient-rich layer. In order to evaluate the diffusivity that was less available in the subsurface layers where indirect estimations are difficult, we conducted direct microstructure measurements in the upper $300 \mathrm{~m}$ of the open Pacific during summer, from $40^{\circ} \mathrm{S}$ to $50^{\circ} \mathrm{N}$ along $170^{\circ} \mathrm{W}$ and from $137^{\circ} \mathrm{E}$ to $120^{\circ} \mathrm{W}$ across the subtropical North Pacific $\left(21^{\circ} 30^{\prime} \mathrm{N}-23^{\circ} \mathrm{N}\right)$. The subsurface pycnocline in the mid- and low-latitude regions was occupied primarily by the Subtropical Underwaters characterized by high salinity, and the Subtropical Mode Waters appeared with an increasing depth and latitude. In the North Pacific, low-salinity subarctic water with shallow seasonal pycnocline was observed in the high-latitude region. The base level of the diffusivity was $0.14-0.47 \times 10^{-5} \mathrm{~m}^{2} \mathrm{~s}^{-1}$, while elevations up to $0.51-13 \times 10^{-5}$ $\mathrm{m}^{2} \mathrm{~s}^{-1}$ were observed at the equator where the Equatorial Undercurrents formed the strong shear in the subsurface layer, and in areas high internal tide energy such as the Hawaiian Ridge. The effect of wind on the diffusivity was less clear, probably because the wind energy is generally low during summer. The shear-to-strain ratio showed dome-shaped profiles with respect to latitude and an increasing trend from west to east in the subtropical North Pacific. The geographical distributions of the diffusivity presented in this study will contribute to better understanding biogeochemical cycles in the stratified upper ocean through improving estimations of the material transport.
\end{abstract}

Keywords Vertical eddy diffusivity $\cdot$ Subsurface pycnocline $\cdot$ Open Pacific

\section{Introduction}

In the open ocean, the subsurface pycnocline develops seasonally in mid- and high-latitude regions and is sustained throughout most of the year in low-latitude regions. The subsurface pycnocline divides well-sunlit/nutrient-poor surface mixed layers and poorly lit/nutrient-rich lower layers (Longhurst 2007). The water exchange between these layers is regulated by the vertical eddy diffusivity that causes upward nutrient transport. The order of magnitude of the vertical eddy diffusivity in the pycnocline (including the subsurface

S. Itoh

itohsach@aori.u-tokyo.ac.jp

1 Atmosphere and Ocean Research Institute, The University of Tokyo, Kashiwa, Japan

2 Japan Agency for Marine-Earth Science and Technology, Yokosuka, Japan

3 Fisheries Resources Institute, Japan Fisheries Research and Education Agency, Shiogama, Japan pycnocline) of the oligotrophic ocean has been estimated as $10^{-5} \mathrm{~m}^{2} \mathrm{~s}^{-1}$ (Gregg 1987; Ledwell et al. 1993; Lewis et al. 1986). While this is much weaker than that of the surface mixed layer, the emergence of a subsurface chlorophyll maximum at the nutricline indicates that vertical eddy diffusivity plays a substantial role in generating new production (Cullen 2015; Furuya 1990).

In addition to the general consensus on its order of magnitude, at least in the open ocean under calm conditions, the vertical eddy diffusivity is known to have substantial temporal and spatial variability. This is attributed in part to the intermittent nature of turbulence (e.g., Baker and Gibson 1987), although geographical variability related to differences in various forcing and background conditions is also important. Waterhouse et al. (2014) compiled profiles of turbulent dissipation rates at various sites and obtained a global map of vertical diffusivity. While the globally averaged vertical diffusivity above $1000 \mathrm{~m}$ was $O\left(10^{-5}\right) \mathrm{m}^{2} \mathrm{~s}^{-1}$, regional variability was evident, explained in part by the levels of local power input by internal tides and wind-driven 
near-inertial waves. Using strain-based estimates of mixing from Argo floats, Whalen et al. (2018) suggested that windinduced mixing in the pycnocline is modulated by mesoscale currents, which also vary geographically in activity and strength. Spatial variability in diffusivity has also been estimated from an inverse method using salinity profiles of Argo floats in the North Pacific (Kouketsu 2018), with results suggesting enhanced diffusivity around prominent topography.

Since the nutrient flux associated with turbulent mixing is likely a major driver of new production in subsurface layers, it is important to refine the estimates of vertical eddy diffusivity in the subsurface pycnocline, especially across a broad geographical range. As this layer is typically above $250 \mathrm{~m}$ and often under the influence of wind-driven geostrophic flows and secondary disturbances, a large number of direct microstructure measurements are required. However, few studies that have presented direct estimates of vertical eddy diffusivity have focused on (1) the subsurface pycnocline just below the surface mixed layer, and (2) its geographical distribution, especially in the Pacific. For the first point, Waterhouse et al. (2014) averaged the diffusivity from the bottom of mixed layer to $1000 \mathrm{~m}$, and Whalen et al. (2018) made evaluations for $250-500 \mathrm{~m}$ at the shallowest. The inverse method by Kouketsu (2018) for solving tracer equations on the isopycnal surface did not cover the near surface layers above $25.0 \sigma_{\theta}$.

For the second point, microstructure profiles in the open Pacific have generally been concentrated around turbulence hot spots (Waterhouse et al. 2014, their fig. 1c) or near the equator (e.g., Inoue et al. 2012), prominent topography such as the Hawaiian Ridge (e.g., Klymak et al. 2006; Rudnick et al. 2003), and strong currents such as the Kuroshio (e.g.,

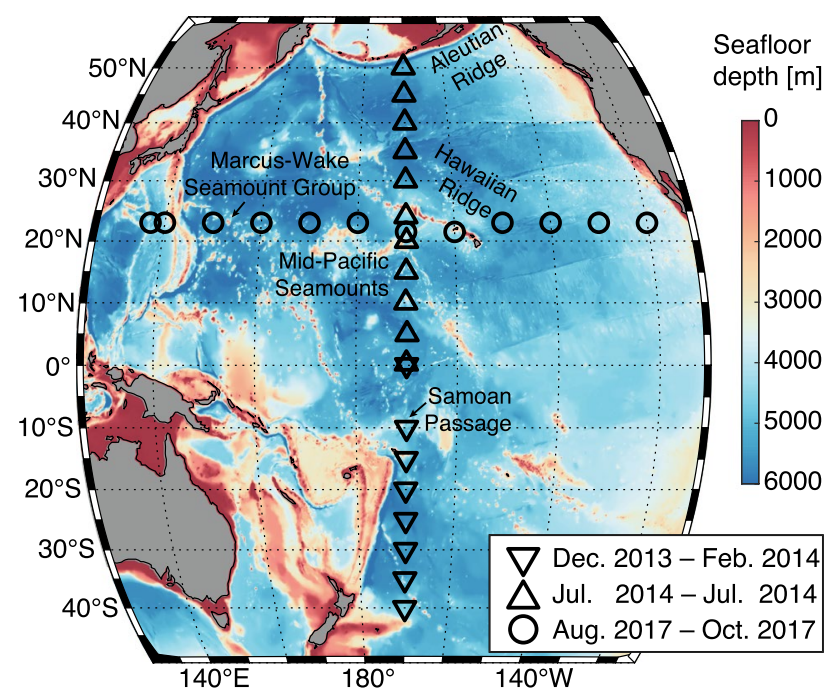

Fig. 1 Stations for microstructure measurements during the three research cruises. Color shading indicates seafloor depth, from Smith and Sandwell (1997)
D’Asaro et al. 2011; Kaneko et al. 2012; Nagai et al. 2009, 2012).

Nevertheless, several studies have conducted turbulence measurements in the Pacific with a regional- or basin-scale coverage (Bouruet-Aubertot et al. 2018; Fernández-Castro et al. 2014; Kaneko et al. 2020; Liu et al. 2017; Mori et al. 2008; Moum and Osborn 1986). Some of these studies proposed various mechanisms enhancing the vertical mixing that could cause geographical variability in upper-layer diffusivity. The observations by Fernández-Castro et al. (2018) covered the western parts of the South Pacific subtropical and tropical regions and the central-to-eastern part of the North Pacific tropical region. The mean vertical diffusivity in the upper pycnocline of these regions was $1.2-3.3 \times 10^{-5}$ $\mathrm{m}^{2} \mathrm{~s}^{-1}$, except for the equatorial area $\left(29-49 \times 10^{-5} \mathrm{~m}^{2} \mathrm{~s}^{-1}\right)$, which is attributed to the vertical velocity shear of the Equatorial Undercurrent (EUC). Bouruet-Aubertot et al. (2018) conducted microstructure measurements in the tropical South Pacific along $\sim 19^{\circ} \mathrm{S}$ from $160^{\circ} \mathrm{E}$ to $160^{\circ} \mathrm{W}$. In their section, the mean vertical eddy diffusivity in the upper $100-500 \mathrm{~m}$ was $0.28-0.60 \times 10^{-5} \mathrm{~m}^{2} \mathrm{~s}^{-1}$, stronger in the west and weaker in the east. The enhancement in the west was explained by an energetic baroclinic near-inertial wave caused by a cyclone.

In this study, we estimate the vertical eddy diffusivity in the subsurface pycnocline along meridional and zonal sections of the Pacific along $170^{\circ} \mathrm{W}$ and $\sim 23^{\circ} \mathrm{N}$. Our main objective is to quantify the magnitude of the diffusivity in the subsurface pycnocline where nutrients are supplied to the subsurface chlorophyll maximum. The remainder of the paper is organized as follows: In Sect. 2, observations and data processing methods are explained. In Sect. 3, we first describe large-scale hydrographic structure across the Pacific and then present the distributions of the intensity of turbulence in the subsurface layer. Distributions of the internal tide and wind forcing conditions, and fine-scale shearto-strain ratio are also examined in this section. Finally in Sect. 4, we made comparisons of our results with previous studies and discuss potential mechanisms enhancing the subsurface turbulence and possible impacts on the nutrient transport.

\section{Materials and methods}

\subsection{Observations and data processing}

Observations were conducted during research cruises KH-13-7, KH-14-3, and KH-17-4 of the R/V Hakuho Maru. The $170^{\circ} \mathrm{W}$ section was observed during KH-13-7 (equator to $40^{\circ} \mathrm{S}$ with a $5^{\circ}$ interval, except for $5^{\circ} \mathrm{S}$ ) and $\mathrm{KH}-14-3$ (equator to $50^{\circ} \mathrm{N}$ with a $\sim 5^{\circ}$ interval), and a section at $\sim 23^{\circ} \mathrm{N}$ $\left(21^{\circ} 30^{\prime} \mathrm{N}-23^{\circ} \mathrm{N}\right.$, with a $10^{\circ}$ interval) was conducted during 
KH-17-4 (Fig. 1 and Table 1). The observations took place during the seasonal stratification seasons in the North and South Pacific, during (from the first station to the last station along the section) December 2013 to January 2014 (KH-137), July 2014 (KH-14-3), and August-October 2017 (KH17-4). The depth of the seafloor at the observation stations exceeds $3000 \mathrm{~m}$, except for $2800 \mathrm{~m}$ at $20^{\circ} \mathrm{N}, 170^{\circ} \mathrm{W}$ near the Mid-Pacific Seamounts (Fig. 1 and Table 1).

At each station, conductivity-temperature-depth (CTD; SBE911plus; SeaBird Electronics Inc.) observations were conducted down to the sea floor (several casts during KH-14-3 were down to $1000 \mathrm{~m}$ ), and expendable CTD (XCTD: Tsurumi Seiki, Co., Ltd.) surveys were carried out between the stations during KH-13-7 and KH-14-3.
Horizontal velocity profiles were recorded continuously throughout the cruise using a shipboard acoustic Doppler current profiler (SADCP; Ocean Surveyor $38 \mathrm{kHz}$; Teledyne RD Instruments). These data from CTD, XCTD, and SADCP were used to describe general hydrographic structure along the transects. Horizontal velocity profiles were also measured at the stations using a lower acoustic Doppler current profiler (LADCP; WorkHorse Monitor $300 \mathrm{kHz}$; Teledyne RD Instruments) mounted on the CTD frame. The LADCP data with higher vertical and lower horizontal resolutions than the SADCP data were analyzed together with the CTD data to estimate shearto-strain ratio $R$. The calculation methods of $R$ are given later in this section.
Table 1 Summary of VMP observations

\begin{tabular}{|c|c|c|c|c|c|c|c|}
\hline Cruise & Station & Latitude & Longitude & Date & Depth & MLD & Profiles ${ }^{* 1}$ \\
\hline \multirow[t]{8}{*}{ KH-13-7 } & $0^{\circ}$ & $0^{\circ} 02^{\prime} \mathrm{N}$ & $170^{\circ} 00^{\prime} \mathrm{W}$ & $23-$ Dec- $2013^{* 2}$ & 5395 & 89 & 2 \\
\hline & $10^{\circ} \mathrm{S}$ & $10^{\circ} 00^{\prime} \mathrm{S}$ & $170^{\circ} 00^{\prime} \mathrm{W}$ & 27-Dec-2013 & 4981 & 39 & 2 \\
\hline & $15^{\circ} \mathrm{S}$ & $15^{\circ} 02^{\prime} \mathrm{S}$ & $170^{\circ} 02^{\prime} \mathrm{W}$ & 03-Jan-2014 & 4809 & 39 & 2 \\
\hline & $20^{\circ} \mathrm{S}$ & $20^{\circ} 00^{\prime} \mathrm{S}$ & $170^{\circ} 05^{\prime} \mathrm{W}$ & 05-Jan-2014 & 5297 & 44 & $3+3+3$ \\
\hline & $25^{\circ} \mathrm{S}$ & $25^{\circ} 00^{\prime} \mathrm{S}$ & $170^{\circ} 02^{\prime} \mathrm{W}$ & 08-Jan-2014 & 5679 & 29 & 3 \\
\hline & $30^{\circ} \mathrm{S}$ & $30^{\circ} 00^{\prime} \mathrm{S}$ & $170^{\circ} 00 \mathrm{~W}$ & 10-Jan-2014 & 5393 & 23 & $3+2$ \\
\hline & $35^{\circ} \mathrm{S}$ & $35^{\circ} 00^{\prime} \mathrm{S}$ & $170^{\circ} 00^{\prime} \mathrm{W}$ & 12-Jan-2014 & 5214 & 27 & 3 \\
\hline & $40^{\circ} \mathrm{S}$ & $40^{\circ} 01^{\prime} \mathrm{S}$ & $170^{\circ} 00 \mathrm{~W}$ & 13-Jan-2014 & 4625 & 28 & 3 \\
\hline \multirow[t]{11}{*}{ KH-14-3 } & $0^{\circ} \mathrm{N}$ & $0^{\circ} 17^{\prime} \mathrm{N}$ & $170^{\circ} 03^{\prime} \mathrm{W}$ & 04-Jul-2014*3 & 5333 & 52 & 1 \\
\hline & $5^{\circ} \mathrm{N}$ & $4^{\circ} 58^{\prime} \mathrm{N}$ & $169^{\circ} 55^{\prime} \mathrm{W}$ & 05-Jul-2014 & 5729 & 77 & 1 \\
\hline & $10^{\circ} \mathrm{N}$ & $10^{\circ} 02^{\prime} \mathrm{N}$ & $170^{\circ} 08^{\prime} \mathrm{W}$ & 07-Jul-2014 & 4369 & 94 & 3 \\
\hline & $15^{\circ} \mathrm{N}$ & $15^{\circ} 01^{\prime} \mathrm{N}$ & $170^{\circ} 01^{\prime} \mathrm{W}$ & 08-Jul-2014 & 5652 & 99 & 1 \\
\hline & $20^{\circ} \mathrm{N}$ & $20^{\circ} 01^{\prime} \mathrm{N}$ & $169^{\circ} 55^{\prime} \mathrm{W}$ & 09-Jul-2014 & 2830 & 39 & 1 \\
\hline & $24^{\circ} \mathrm{N}$ & $24^{\circ} 04^{\prime} \mathrm{N}$ & $170^{\circ} 00^{\prime} \mathrm{W}$ & 11-Jul-2014 & 4640 & 40 & 2 \\
\hline & $30^{\circ} \mathrm{N}$ & $30^{\circ} 00^{\prime} \mathrm{N}$ & $170^{\circ} 03^{\prime} \mathrm{W}$ & 20-Jul-2014 & 5425 & 22 & 2 \\
\hline & $35^{\circ} \mathrm{N}$ & $35^{\circ} 01^{\prime} \mathrm{N}$ & $170^{\circ} 00^{\prime} \mathrm{W}$ & 22-Jul-2014 & 5876 & 27 & 2 \\
\hline & $40^{\circ} \mathrm{N}$ & $40^{\circ} 02^{\prime} \mathrm{N}$ & $170^{\circ} 00^{\prime} \mathrm{W}$ & 23-Jul-2014 & 5270 & 20 & 1 \\
\hline & $45^{\circ} \mathrm{N}$ & $45^{\circ} 02^{\prime} \mathrm{N}$ & $170^{\circ} 03^{\prime} \mathrm{W}$ & 25-Jul-2014 & 6186 & 14 & 1 \\
\hline & $50^{\circ} \mathrm{N}$ & $50^{\circ} 04^{\prime} \mathrm{N}$ & $170^{\circ} 06^{\prime} \mathrm{W}$ & 26-Jul-2014 & 5191 & 27 & 1 \\
\hline \multirow[t]{12}{*}{ КН-17-4 } & $120^{\circ} \mathrm{W}$ & $23^{\circ} 00^{\prime} \mathrm{N}$ & $120^{\circ} 00^{\prime} \mathrm{W}$ & 22-Aug-2017 & 4141 & 37 & $3+3$ \\
\hline & $130^{\circ} \mathrm{W}$ & $23^{\circ} 00^{\prime} \mathrm{N}$ & $130^{\circ} 01^{\prime} \mathrm{W}$ & 24-Aug-2017 & 4693 & 19 & 2 \\
\hline & $140^{\circ} \mathrm{W}$ & $23^{\circ} 00^{\prime} \mathrm{N}$ & $140^{\circ} 00^{\prime} \mathrm{W}$ & 27-Aug-2017 & 5015 & 44 & $3+3$ \\
\hline & $150^{\circ} \mathrm{W}$ & $23^{\circ} 00 .^{\prime} \mathrm{N}$ & $150^{\circ} 00^{\prime} \mathrm{W}$ & 30-Aug-2017 & 5451 & 40 & 3 \\
\hline & $160^{\circ} \mathrm{W}$ & $21^{\circ} 30^{\prime} \mathrm{N}$ & $160^{\circ} 00^{\prime} \mathrm{W}$ & 03-Sep-2017 & 3893 & 50 & $2+3$ \\
\hline & $170^{\circ} \mathrm{W}$ & $21^{\circ} 31^{\prime} \mathrm{N}$ & $170^{\circ} 00^{\prime} \mathrm{W}$ & 14-Sep-2017 & 4718 & 36 & $2+2+3$ \\
\hline & $179^{\circ} \mathrm{W}$ & $23^{\circ} 00^{\prime} \mathrm{N}$ & $180^{\circ} 00^{\prime}$ & 16-Sep-2017 & 5347 & 48 & 3 \\
\hline & $170^{\circ} \mathrm{E}$ & $23^{\circ} 00^{\prime} \mathrm{N}$ & $170^{\circ} 00^{\prime} \mathrm{E}$ & 19-Sep-2017 & 5913 & 23 & 3 \\
\hline & $160^{\circ} \mathrm{E}$ & $23^{\circ} 00^{\prime} \mathrm{N}$ & $160^{\circ} 00^{\prime} \mathrm{E}$ & 22-Sep-2017 & 5467 & 33 & $3+3$ \\
\hline & $150^{\circ} \mathrm{E}$ & $23^{\circ} 00^{\prime} \mathrm{N}$ & $150^{\circ} 00^{\prime} \mathrm{E}$ & 26-Sep-2017 & 5714 & 35 & 3 \\
\hline & $140^{\circ} \mathrm{E}$ & $23^{\circ} 01^{\prime} \mathrm{N}$ & $140^{\circ} 00^{\prime} \mathrm{E}$ & 29-Sep-2017 & 4122 & 30 & 3 \\
\hline & $137^{\circ} \mathrm{E}$ & $23^{\circ} 01^{\prime} \mathrm{N}$ & $137^{\circ} 00^{\prime} \mathrm{E}$ & 01-Oct-2017 & 3047 & 29 & 3 \\
\hline
\end{tabular}

${ }^{*}$ Profile number in format $N+M+L$ indicates $N, M$, and $L$ consecutive measurements were conducted with a typical interval of $6-12 \mathrm{~h}$

${ }^{* 2}$ During 17:52-18:17 (local time)

${ }^{* 3}$ During 23:32-23:38 (local time) 
A vertical microstructure profiler (VMP-250; Rockland Scientific) was deployed 1-9 times at the station same as the CTD (Table 1). The instrument, which was attached with a thin tether, measured and internally recorded microstructure data while free-falling with a nominal speed of $0.4-0.8 \mathrm{~m} \mathrm{~s}^{-1}$ down to the maximum tether length. The microscale velocity data obtained from two shear probes were processed using the software provided by the manufacturer, which integrates wavenumber spectra of microscale velocity shear within temporal bins (in the present case, 8 -s bins) to obtain the turbulent kinetic energy dissipation rate $\varepsilon$ (Wolk et al. 2002). If the spectra were not consistent with the Nasmyth universal spectrum, the corresponding data were manually excluded. The two $\varepsilon$ values at each bin from the two shear probes were averaged if they were within a factor of 4 , or otherwise the smaller one was taken as in Fer et al. (2014). The $\varepsilon$ profiles were interpolated at a 1-m interval, and then, multiple profiles were averaged to obtain the mean profile $\langle\varepsilon\rangle$ for each station. Mean profiles of buoyancy frequency $\left\langle N^{2}\right\rangle$ at each station were calculated using the conductivity-temperature sensor attached to the VMP-250. The vertical eddy diffusivity was then obtained as $\left\langle K_{\rho}\right\rangle=\Gamma\langle\varepsilon\rangle\left\langle\left\langle N^{2}\right\rangle\right.$ (Osborn 1980), where $\Gamma=0.2$ was assumed.

\subsection{Averaging over the subsurface pycnocline}

To highlight the geographical distribution, the depth-averaged turbulence properties $\overline{\langle\varepsilon\rangle}$ and $\overline{\left\langle K_{\rho}\right\rangle}$ in the subsurface pycnocline were also estimated with confidence intervals. To do this, we first calculated the vertical average of the ensemble-means (hereafter called ensemble and vertical average) energy dissipation rate $\overline{\langle\varepsilon\rangle}$ with $95 \%$ confidence intervals over the 150 -m layer from $10 \mathrm{~m}$ below the surface mixed layer, using the bootstrap method. The mixed layer depth was defined as the depth where the ensemble-mean potential density exceeds that at $10 \mathrm{~m}$ by $0.125 \mathrm{~kg} \mathrm{~m}^{-3}$. We adopted this large potential density difference, which is often used for climatological data sets (Levitus 1983), to exclude data within any remnant mixed layer that had developed in the short term (e.g., a nighttime mixed layer). Although the diurnal cycle of turbulence is prominent in the equatorial area even below the mixed layer (e.g., Gregg et al. 1985), we presume that the above criterion selects the layer with less diurnal variation, which was termed the upper core layer (of the Equatorial Undercurrent) by Inoue et al. (2012). In estimating the confidence interval, a fixed decorrelation scale of $10 \mathrm{~m}$ was adopted, which was greater than the median values of 6-8 $\mathrm{m}$ based on vertical autocorrelation of $\log (\varepsilon)$.

A $150-\mathrm{m}$ bin was selected so that the subsurface chlorophyll maximum was included within the bin. As the mean profiles at the equator were limited to depths of $190 \mathrm{~m}$ and $119 \mathrm{~m}$ during austral and boreal summer, respectively, $\overline{\langle\varepsilon\rangle}$ was calculated using the available data for the former (a 91-m layer) but not calculated for the latter. The ensemble and vertical average of $\overline{\left\langle N^{2}\right\rangle}$ were calculated similarly, and $\overline{\left\langle K_{\rho}\right\rangle}$ was obtained as for $\left\langle K_{\rho}\right\rangle$.

\subsection{Forcing factors and shear-to-strain ratio}

The geographical distribution of $\overline{\langle\varepsilon\rangle}$ and $\overline{\left\langle K_{\rho}\right\rangle}$ is compared with major forcing factors that could enhance the turbulence. We consider the influences of internal tide and wind power on the turbulence in the subsurface pycnocline. This is done so following Waterhouse et al. (2014) that focused on the source terms for the internal wave field, instead of wavebreaking processes.

Energy dissipation caused by the internal tide can occur through multiple pathways, with source waves from either remote or local fields. We use the $0.5^{\circ}$-resolution dataset of temporally and vertically averaged total dissipation rate caused by the internal tide (de Lavergne et al. 2019), which is denoted in the present study as $D_{\text {tide }}$. From the global map, $D_{\text {tide }}$ values were spatially interpolated onto the positions of our stations, to indicate the potential influence of the internal tide. We selected $D_{\text {tide }}$ instead of simpler parameters such as the barotropic-to-baroclinic conversion rate, in order to consider the effects of far-field internal tide dissipation to diffusivity (de Lavergne et al. 2019). Although $D_{\text {tide }}$ is temporally averaged, our estimations of $\overline{\langle\varepsilon\rangle}$ and $\overline{\left\langle K_{\rho}\right\rangle}$ at each station are derived mostly from snapshot observations. Therefore, some of variability of near-field mixing, included in the observation-based products of $\overline{\langle\varepsilon\rangle}$ and $\overline{\left\langle K_{\rho}\right\rangle}$, cannot be directly compared with $D_{\text {tide }}$. However, as presented in previous studies such as Waterhouse et al. (2014), dissipation rates from individual profiles were generally related to the averaged power input from tide.

The impact of wind is considered in terms of the local turbulent energy production by the wind $\rho_{0} u^{* 3}$, where $u^{*}$ and $\rho_{0}$ are the friction velocity and the upper-layer water density, respectively. Hourly wind stress data from the second Modern-Era Retrospective analysis for Research and Applications (MERRA2; Geralo et al. 2017) were extracted at the locations of stations, and the temporal average calculated for 10 days until the mean time of VMP-250 deployments, and then, $\rho_{0} u^{* 3}$ was calculated assuming $\rho_{0}=1025 \mathrm{~kg} \mathrm{~m}^{-3}$; herein, this is denoted as $E_{\text {wind }}$. The duration of 10 days was employed considering the duration of 30-50 days used in Whalen et al. (2018) focusing on deeper layers of 250-500 m, while the geographical pattern of $E_{\text {wind }}$ did not show substantial changes with different durations in ranges of 1-30 days.

To examine the regime of the fine-scale variability influencing the turbulence in the subsurface pycnocline, the shear-to-strain ratio was estimated from the CTD and the LADCP data. For internal waves with a single frequency, 
this parameter was often denoted as $R_{\omega}$ and measures the frequency content as $R_{\omega} \simeq\left(\omega^{2}+f^{2}\right) /\left(\omega^{2}-f^{2}\right)$ (e.g., Chinn et al. 2016; Kunze et al. 2006), where $\omega$ and $f$ are the internal wave and inertial frequencies, respectively. Although the variations in the subsurface pycnocline just below the mixed layer do not likely follow this simple formulation, the shear-to-strain ratios themselves can be calculated from our data, which in the present study is denoted as $R$.

In calculating $R$, the raw CTD and LADCP data were first processed using the Seasave V7 (https://www.seabi rd.com/software) and LDEO software IX (https://www. ldeo.columbia.edu/ ant/LADCP.html; Thurnherr 2010), respectively. The detrended strain profiles for the $500-\mathrm{m}$ bin below the surface mixed layer (mixed layer $+10 \mathrm{~m}$ - mixed layer $+510 \mathrm{~m}$ ) were obtained from the buoyancy frequency $N^{2}$ calculated from the 1-m interval CTD data as $\xi_{z}=\left[N^{2}\right]^{\prime} /\left[\bar{N}^{2}\right]$, where overbar denotes 500-m-bin average and []' indicates vertical detrending that is to eliminate the strong gradient of $N^{2}$ in the subsurface. The detrended shear profiles $\left(U_{z}, V_{z}\right)$ for the 500-m bin were similarly obtained from the $10-\mathrm{m}$ interval LADCP data. The strain and shear spectra (normalized by the buoyancy frequency) were obtained as $\phi_{s t}=S\left(\xi_{z}\right)$ and $\phi_{s h}=S\left(U_{z}\right) / \overline{N^{2}}+S\left(V_{z}\right) / \overline{N^{2}}$, where $S(f)$ denotes a wavenumber spectrum of a profile $f$. These spectra were then integrated over the range from $k_{\min }=1 / 200$ to $k_{\max }=1 / 50$ cpm as
$\left(\Phi_{s t}, \Phi_{s h}\right)=\int_{k_{\min }}^{k_{\max }}\left(\phi_{s t}(k), \phi_{s h}\right) d k$

and then $R$ was estimated as

$R=\frac{\Phi_{s h}}{\Phi_{s t}}$

The interval of integration $[1 / 200,1 / 50]$ was carefully selected to represent the scale of the bin-averaging $(150 \mathrm{~m})$ and not to include the range where shear spectra are attenuating. The confidence intervals of the spectral estimates of $R$ were calculated using the bootstrap method.

\section{Results}

\subsection{General hydrography}

The meridional section along $170^{\circ} \mathrm{W}$ penetrated the subarctic gyre, the two subtropical gyres and the equatorial current systems, and the zonal section ran through the middle of the subtropical gyre in the North Pacific (Fig. 2). The mesoscale variability was relatively low along $170^{\circ} \mathrm{W}$ and the eastern North Pacific. From central to western North Pacific along the zonal section, the amplitude of the mesoscale variability showed moderate level of $\sim 0.2 \mathrm{~m}$, which is attributed to

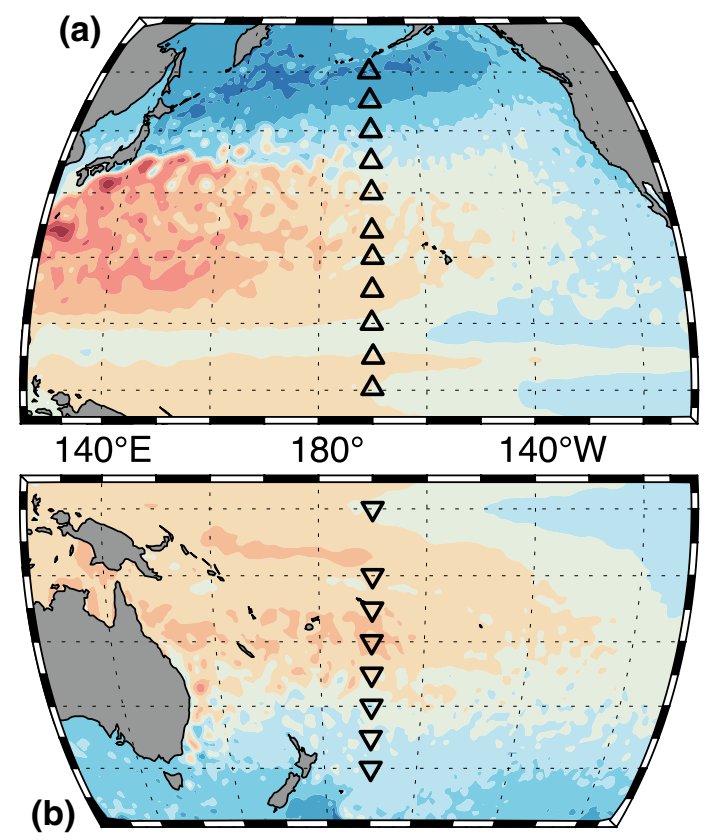

Fig. 2 Station plots on maps of absolute dynamic topography, based on the satellite altimetry data produced by the Copernicus Marine Environment Monitoring Service (http://marine.copernicus.eu/), which is averaged over the observation periods of each cruise: (a)

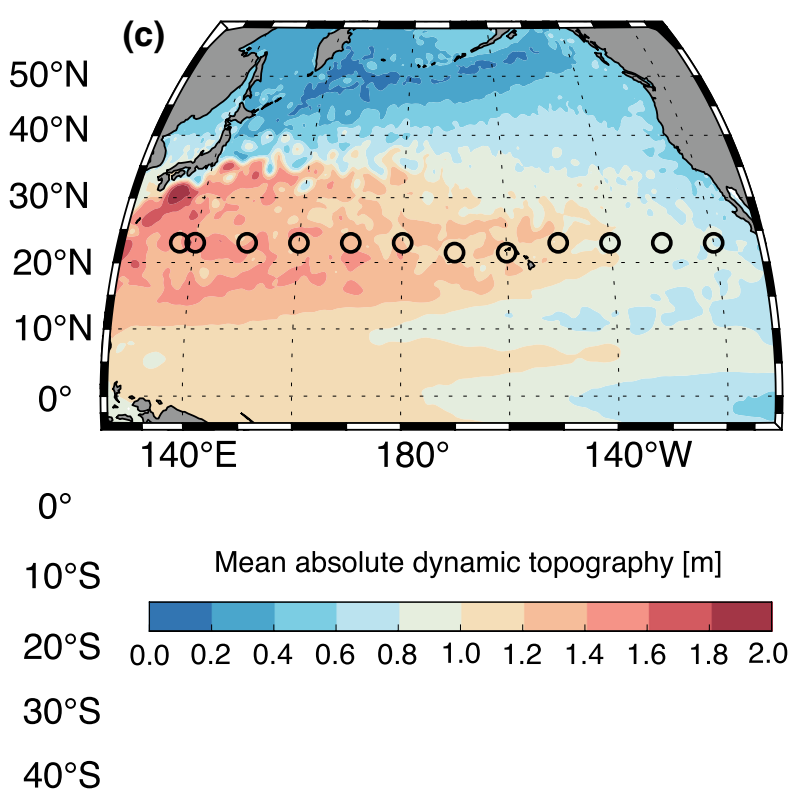

KH-13-7 during austral summer in 2013/2014, (b) KH-14-3 during boreal summer in 2014 and (c) KH-17-4 during boreal summer in 2017 
mesoscale eddies associated with the Subtropical Counter Currents.

The subsurface pycnocline appears either as the seasonal pycnocline in the mid- and high-latitude regions or the permanent pycnocline in the low-latitude regions (Fig. 3). The main pycnocline is shallow in the equatorial area, but generally deeper than the seasonal pycnocline in the higher-latitude regions. The salinity profiles clearly depicted the water mass distributions in these pycnoclines. In the mid- and low-latitude South Pacific, subsurface pycnoclines were mostly occupied by the high salinity water of $>35.0$, which is defined as the South Pacific Subtropical Underwater (STUW) in the upper part and the South Pacific Subtropical Mode Water (STMW) in the lower part (Talley et al. 2011; Fig. 3a). In the North Pacific, the occurrence of the North Pacific STUW was confined in the upper layer/ lower latitude, and the North Pacific STMW and the North Pacific Central Mode Water (CMW) characterized by the thick layer were more clearly observed in $25-40^{\circ} \mathrm{N}$ than the South Pacific (Oka and Qiu 2011). On the southern and northern sides of the saline water outcropped to the surface around the equator, the low-salinity pool associated with the Intertropical Convergence Zone (ITCZ) occurred above the pycnocline in $5-12^{\circ}$. In the North Pacific, the prominently fresh subarctic water that was connected to the North Pacific Intermediate Water (NPIW) was observed (Fig. 3b). For the zonal section, the subsurface pycnocline mainly consisted of the North Pacific STUW west of $140^{\circ} \mathrm{W}$, while the North Pacific Eastern STMW (Hanawa and Talley 2001) was recognized in $140-130^{\circ} \mathrm{W}$ (Fig. 3c). Although the mode waters are characterized by pycnostads rather than a pycnocline, we include them in the calculation of the $\overline{\langle\varepsilon\rangle}, \overline{\left\langle N^{2}\right\rangle}$, and $\overline{\left\langle K_{\rho}\right\rangle}$ terms that are defined as the mean dissipation rate, stratification, and diffusivity in the subsurface pycnocline, respectively, considering the connectivity of the diffusive transport at the scale of $O(100) \mathrm{m}$.

Horizontal velocity in the upper layer was moderate along both of the meridional and zonal sections, except in the equatorial area (Fig. 4). The prominent eastward jet of the Equatorial Undercurrent was observed, where maximum eastward speed exceeded $0.7 \mathrm{~m} \mathrm{~s}^{-1}$ at the core. The surface-intensified eastward flows at slightly higher latitudes are the North and South Equatorial Counter Currents, and the westward currents in $8-16^{\circ} \mathrm{N}$ and $13-22^{\circ} \mathrm{S}$ are North and South Equatorial Currents, respectively. The eastward speed of the North and South Pacific Currents originating from the western boundary currents was mostly less than $5 \mathrm{~cm} \mathrm{~s}^{-1}$ at $170^{\circ} \mathrm{W}$ (Fig. $4 \mathrm{a}$, b). Being along the middle of the North Pacific subtropical gyre, velocity across the zonal section was not driven by the large-scale current system but by mesoscale disturbances with moderate amplitudes (Fig. 4c; see also Fig. 2c).
Fig. 3 Vertical cross sections of the salinity (color shading) obtained using data from conductivity-temperature-depth (CTD) measurements at the stations and from expendable CTD (XCTD) deployed between the stations: (a and b) meridional sections in the South and North Pacific along $170^{\circ} \mathrm{W}$, and (c) zonal section in the subtropical North Pacific along $21^{\circ} 30^{\prime} \mathrm{N}-23^{\circ} \mathrm{N}$. The gray contour lines, blue solid lines, and blue dashed lines indicate potential density $\left[\mathrm{kg} \mathrm{m}^{-3}\right]$, mixed layer depth, and the lower bound of the turbulence averaging, respectively

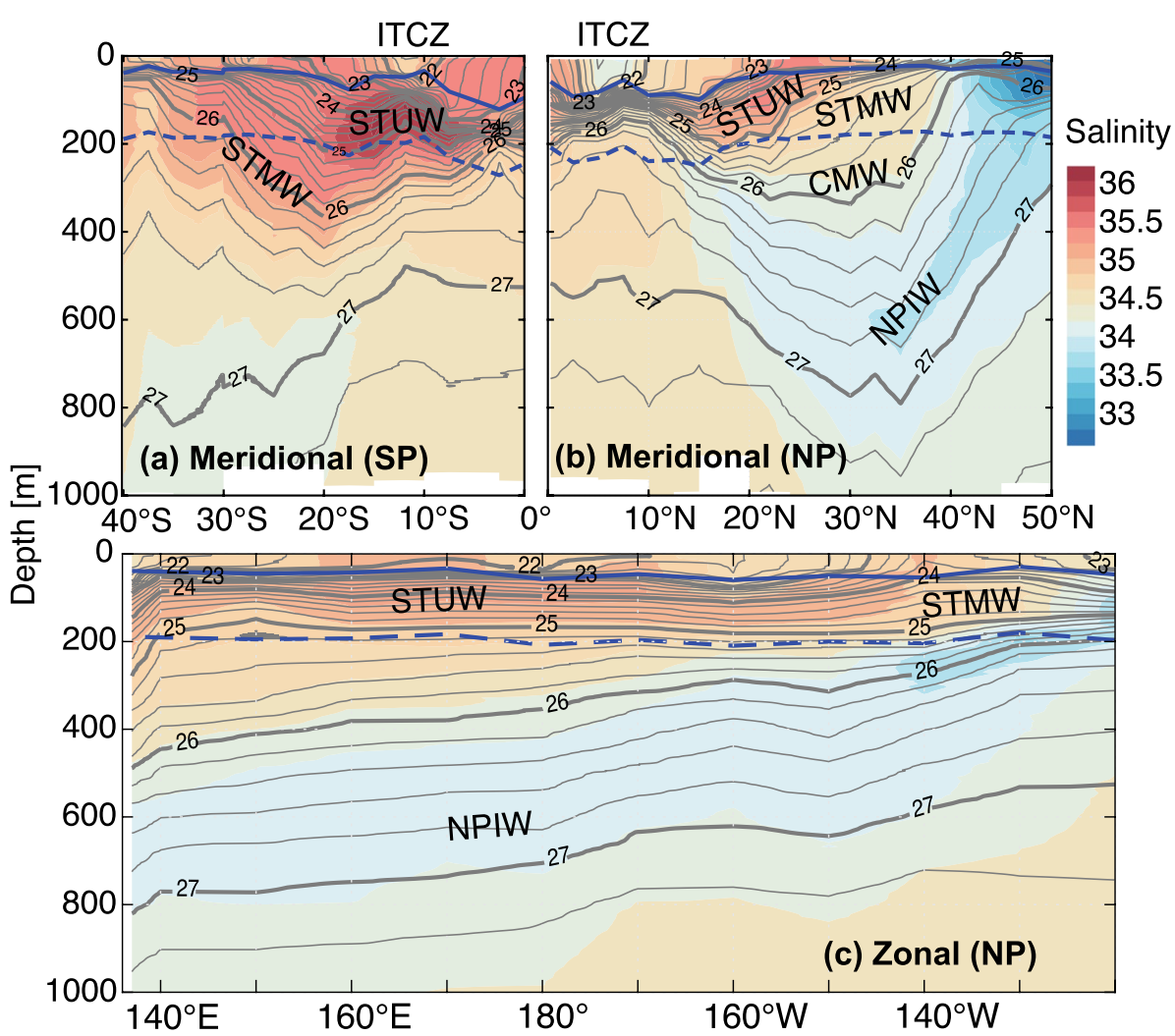




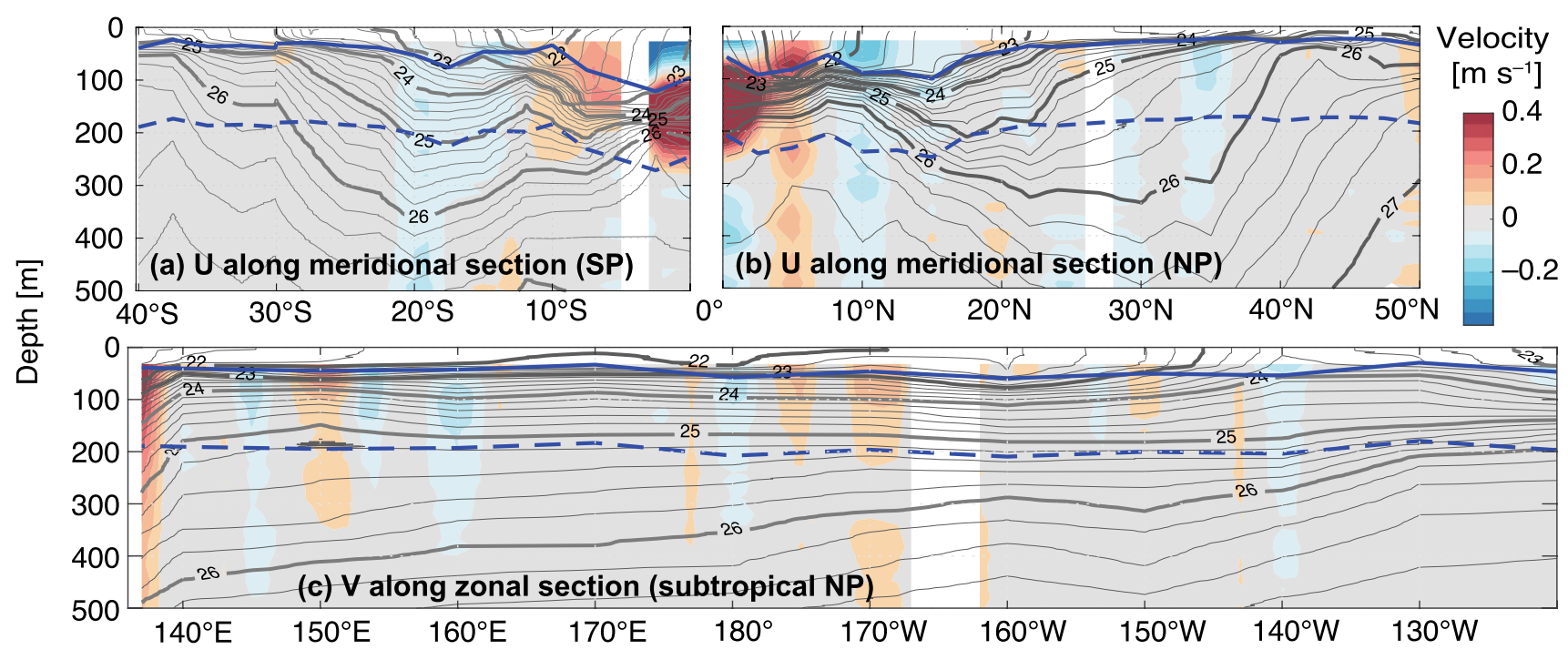

Fig. 4 Same as Fig. 3 but for the horizontal velocity (color shading) as observed by shipboard acoustic Doppler current profiler: (a and b) eastward velocity along the meridional sections, and (c) northward

\subsection{Turbulence in the subsurface pycnocline}

The turbulent kinetic energy dissipation rate $\langle\varepsilon\rangle$ in the subsurface pycnocline below the surface mixed layer shows large variability along both meridional and zonal sections (Fig. 5). It is notably enhanced at the equator, exceeding $10^{-7} \mathrm{~W} \mathrm{~kg}^{-1}$, while relatively high values of $\langle\varepsilon\rangle\left(3-30 \times 10^{-9} \mathrm{~W} \mathrm{~kg}^{-1}\right)$ are also intermittently observed within the pycnocline over wide areas. We found occurrences of narrow layers of elevated turbulence (typically with $<10 \mathrm{~m}$ and $>10^{-8.5} \sim 3 \times 10^{-9} \mathrm{~W} \mathrm{~kg}^{-1}$ ) away from the velocity along the zonal section. Gray color shows that speed was less than $5 \mathrm{~cm} \mathrm{~s}^{-1}$, and the white areas indicate that the data were not available

equator at $10^{\circ} \mathrm{S}, 10^{\circ} \mathrm{N}$, and $50^{\circ} \mathrm{N}$ along $170^{\circ} \mathrm{W}$ (Fig. 5a, b), and $150^{\circ} \mathrm{E}, 170^{\circ} \mathrm{W}, 160^{\circ} \mathrm{W}$, and $120^{\circ} \mathrm{W}$ along the subtropical North Pacific (Fig. 5c). As seen in Fig. 1, these stations, except for $120^{\circ} \mathrm{W}$, located around the prominent topographic features $\left(10^{\circ} \mathrm{S}\right.$ : Samoan Passage, $10^{\circ} \mathrm{N}$ : Mid-Pacific Seamounts, $50^{\circ} \mathrm{N}$ : Aleutian Ridge, $150^{\circ} \mathrm{E}$ : Marcus-Wake Seamount Group, $170^{\circ} \mathrm{W}$ : Mid-Pacific Seamounts and $160^{\circ} \mathrm{W}$ : Hawaiian Ridge; Fig. 1).

The elevation of $\left\langle K_{\rho}\right\rangle$ basically followed that of $\langle\varepsilon\rangle$ (Fig. 6). It exceeds $10^{-4} \mathrm{~m}^{2} \mathrm{~s}^{-1}$ at the equator, and moderately high values $\left(10^{-5}\right.$ to $\left.10^{-4} \mathrm{~m}^{2} \mathrm{~s}^{-1}\right)$ are observed in areas mentioned

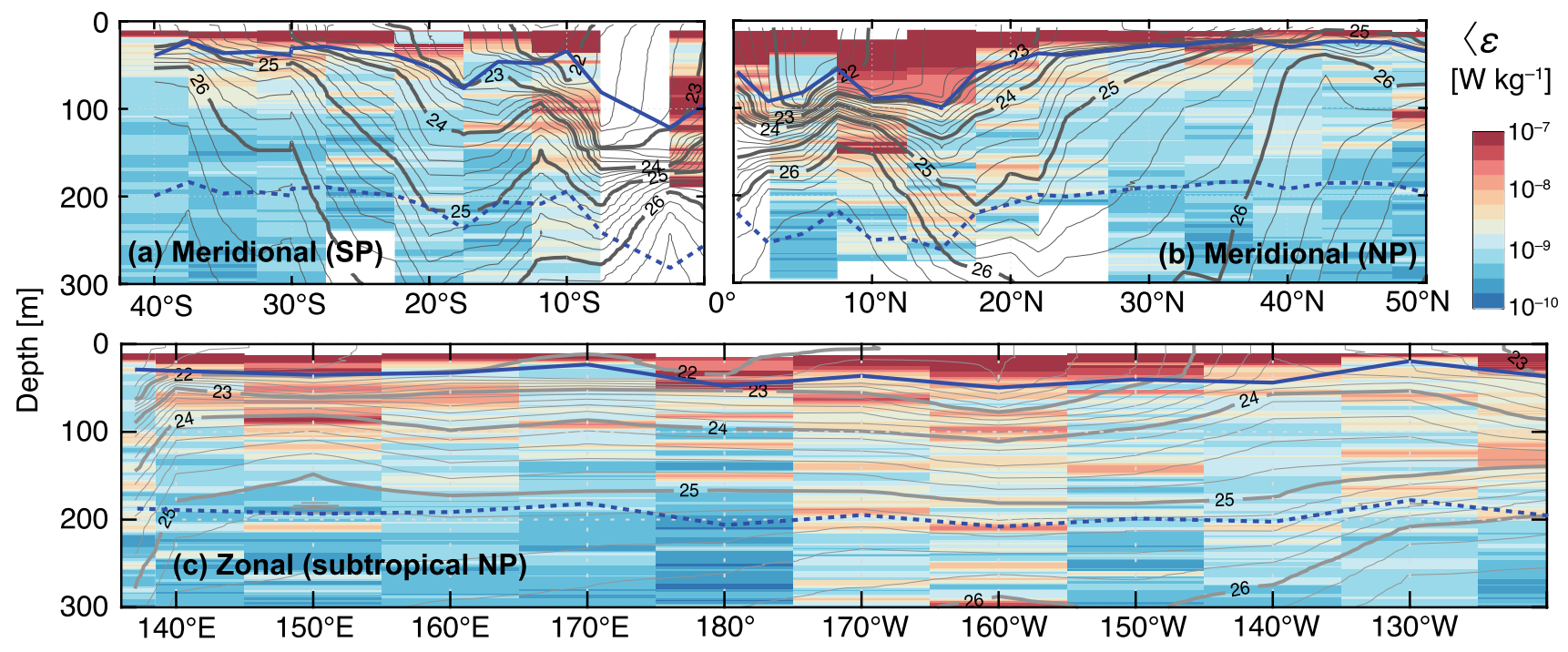

Fig. 5 Same as Fig. 3 but for turbulent kinetic energy dissipation rate (color shading): (a and $\mathbf{b})$ along the meridional sections, and (c) along the zonal section 


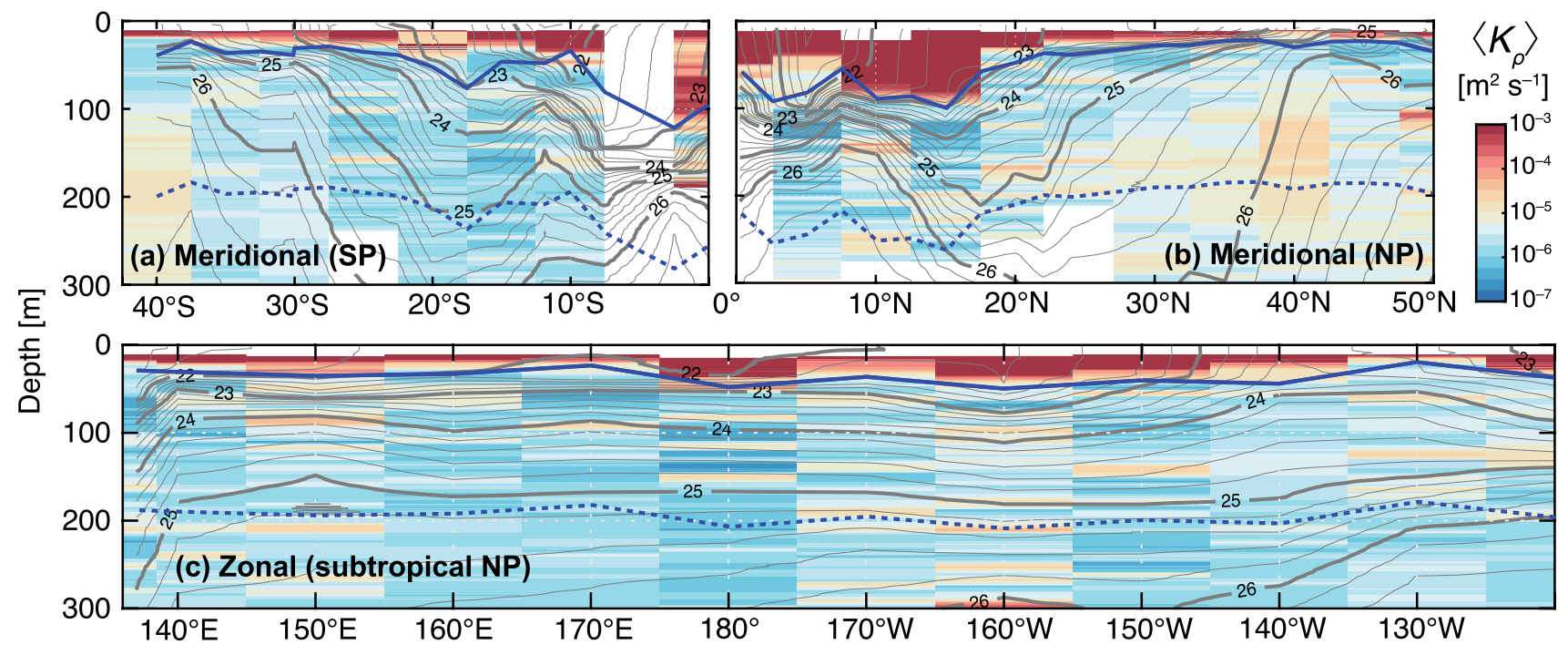

Fig. 6 Same as Fig. 3 but for vertical eddy diffusivity (color shading): (a and $\mathbf{b}$ ) along the meridional sections, and (c) along the zonal section

above. The difference between $\left\langle K_{\rho}\right\rangle$ and $\langle\varepsilon\rangle$ caused by the $\left\langle N^{2}\right\rangle$ variation was typically found both at the layers of peak $\left\langle N^{2}\right\rangle$ (decrease $\left\langle K_{\rho}\right\rangle$ ) and those of mode waters (increase $\left\langle K_{\rho}\right\rangle$ ) over $30-40^{\circ} \mathrm{N}, 40^{\circ} \mathrm{S}$, and $130^{\circ} \mathrm{W}$.

The ensemble and vertical mean dissipation rate $\overline{\langle\varepsilon\rangle}$ and diffusivity $\overline{\left\langle K_{\rho}\right\rangle}$ are shown in Fig. 7 and Table 2. We defined stations with elevated turbulence as those in the upper $25 \%$ of $\varepsilon$ in the subsurface pycnocline of all stations (i.e., values $\geq 3.9 \times 10^{-9} \mathrm{~W} \mathrm{~kg}^{-1}$, thick dashed lines in Fig. $7 \mathrm{a}, \mathrm{b}$ ), excluding those at the equator where extremely high $\varepsilon$ was observed, and we defined stations with values below the $25 \%$ level as base-level stations. The estimated $\overline{\langle\varepsilon\rangle}$ at the base-level stations (open symbols in Fig. 7a, b) range from $0.96 \times 10^{-9}$ to $3.6 \times 10^{-9} \mathrm{~W} \mathrm{~kg}^{-1}$, while those at stations of elevated turbulence (solid symbols) are $4.9 \times 10^{-9}$ to $14 \times 10^{-9} \mathrm{~W} \mathrm{~kg}^{-1}$ (except for the equator). The $\overline{\langle\varepsilon\rangle}$ at the equator exceeds $10^{-7} \mathrm{~W} \mathrm{~kg}^{-1}$, although the confidence interval is wide because of the patches of extremely high $\varepsilon$ (Fig. 5).

The $\overline{\left\langle K_{\rho}\right\rangle}$ at the base-level stations (open symbols in Fig. $7 \mathrm{c}, \mathrm{d})$ fell within the range $0.14-0.47 \times 10^{-5} \mathrm{~m}^{2} \mathrm{~s}^{-1}$. Even the upper bound of the confidence intervals did not reach $10^{-5} \mathrm{~m}^{2} \mathrm{~s}^{-1}$, except for the station with Central Mode Water at $40^{\circ} \mathrm{N}, 170^{\circ} \mathrm{W}$. The elevation of $\overline{\left\langle K_{\rho}\right\rangle}$ from the base level was defined in a similar way to that for $\overline{\langle\varepsilon\rangle}$. The $\overline{\left\langle K_{\rho}\right\rangle}$ of the elevated stations away from the equator was $0.51-1.4 \times 10^{-5}$ $\mathrm{m}^{2} \mathrm{~s}^{-1}$, and $13 \times 10^{-5} \mathrm{~m}^{2} \mathrm{~s}^{-1}$ at the equator.

\subsection{Internal tide, wind, stratification and shear-to-strain ratio}

In this subsection, we compare the geographical distributions of the mixing intensity with those of the forcing and background condition. The two forcing factors $D_{\text {tide }}$ and $E_{\text {wind }}$, and $\overline{\left\langle N^{2}\right\rangle}$ scaling velocity from internal waves (e.g., Leaman and Sanford, 1975) that could be forced by tide and/ or wind are shown in Fig. 8, and the shear-to-strain ratio $R$ that is indicative of the regime of the fine-scale variability is shown in Fig. 9.

Although the depth of the seafloor at the observation stations exceeds $3000 \mathrm{~m}$, except for $\sim 2800 \mathrm{~m}$ at $20^{\circ} \mathrm{N}, 170^{\circ} \mathrm{W}$ near the Mid-Pacific Seamounts (Fig. 1 and Table 1), there is some correspondence between the model-based vertically integrated dissipation rate $D_{\text {tide }}$ and vertical mixing (Fig. 8a, b). The enhanced vertical diffusivity $\overline{\left\langle K_{\rho}\right\rangle}$ near the Hawaiian Ridge and the Mid-Pacific Seamounts at $170^{\circ} \mathrm{W}$ and $160^{\circ} \mathrm{W}$ along the zonal transect (Fig. 8b) is likely caused by the internal tide, where the model of de Lavergne et al. (2019) predicts high $D_{\text {tide. }}$. The relatively high $D_{\text {tide }}$ is also predicted at $10^{\circ} \mathrm{S}$ (Fig. 8a) and $150^{\circ} \mathrm{E}$ (Fig. 8b). However, despite high $D_{\text {tide }}$ at $15^{\circ} \mathrm{S}$ and over $15-24^{\circ} \mathrm{N}$ along $170^{\circ} \mathrm{W}$ (Fig. 8a), and $137^{\circ} \mathrm{E}$ and $140^{\circ} \mathrm{E}$ along $23^{\circ} \mathrm{N}$ (Fig. 8b), turbulence is not elevated (Fig. 7). As seen in Figs. 5, 6, patches of elevated turbulence are observed around the lower bounds of, and in layers deeper than, the averaging bin (10 to $160 \mathrm{~m}$ below the mixed layer) at these stations, suggesting weaker penetration of the internal wave energy to the upper layer.

The turbulent energy production by wind $\left(E_{\text {wind }}\right)$ averaged over 10 days at the observation stations was moderate with a level comparable to or lower than $10^{-3} \mathrm{~W} \mathrm{~m}^{-2}$ (corresponding to a wind stress magnitude of $\sim 0.1 \mathrm{~N} \mathrm{~m}^{-2}$; Fig. $8 \mathrm{c}, \mathrm{d}$ ). While the estimates change slightly for different averaging times ( 1 day or 30 days; not shown), the pattern is similar to the climatology of wind power on inertial motions during summer (e.g., Alford 2003). Among the stations where 
Table 2 Mean dissipation rate and diffusivity in the subsurface pycnocline

\begin{tabular}{|c|c|c|c|}
\hline Cruise & Station & $\begin{array}{l}\text { Dissipation rate } \\
{\left[10^{-9} \mathrm{~W} \mathrm{~kg}^{-1}\right](95 \%} \\
\text { confidence Interval })\end{array}$ & $\begin{array}{l}\text { Diffusivity }\left[10^{-5} \mathrm{~m}^{2} \mathrm{~s}^{-1}\right] \\
\text { (95\% confidence Interval) }\end{array}$ \\
\hline \multirow{8}{*}{$\begin{array}{l}\mathrm{KH}- \\
13-7\end{array}$} & $0^{\circ} \mathrm{S}$ & $168(17-671)$ & $13(1.2-53)$ \\
\hline & $10^{\circ} \mathrm{S}$ & $5.5(3.3-8.5)$ & $0.51(0.30-0.80)$ \\
\hline & $15^{\circ} \mathrm{S}$ & $1.6(0.8-2.9)$ & $0.24(0.12-0.40)$ \\
\hline & $20^{\circ} \mathrm{S}$ & $1.3(1.1-1.7)$ & $0.26(0.21-0.32)$ \\
\hline & $25^{\circ} \mathrm{S}$ & $1.5(0.8-2.4)$ & $0.27(0.15-0.46)$ \\
\hline & $30^{\circ} \mathrm{S}$ & $2.1(1.4-3.0)$ & $0.36(0.25-0.51)$ \\
\hline & $35^{\circ} \mathrm{S}$ & $1.7(1.0-2.5)$ & $0.37(0.24-0.54)$ \\
\hline & $40^{\circ} \mathrm{S}$ & $1.0(0.7-1.3)$ & $0.27(0.20-0.39)$ \\
\hline \multirow{11}{*}{$\begin{array}{l}\mathrm{KH}- \\
14-3\end{array}$} & $0^{\circ} \mathrm{N}$ & - & - \\
\hline & $5^{\circ} \mathrm{N}$ & $2.3(1.3-3.5)$ & $0.14(0.08-0.24)$ \\
\hline & $10^{\circ} \mathrm{N}$ & $14(4.2-42)$ & $1.06(0.34-3.04)$ \\
\hline & $15^{\circ} \mathrm{N}$ & $2.3(1.4-3.5)$ & $0.24(0.13-0.42)$ \\
\hline & $20^{\circ} \mathrm{N}$ & $3.3(1.6-5.8)$ & $0.47(0.24-0.81)$ \\
\hline & $24^{\circ} \mathrm{N}$ & $1.8(1.1-3.1)$ & $0.45(0.27-0.77)$ \\
\hline & $30^{\circ} \mathrm{N}$ & $1.2(0.9-1.6)$ & $0.27(0.18-0.40)$ \\
\hline & $35^{\circ} \mathrm{N}$ & $2.0(1.1-3.3)$ & $0.44(0.27-0.73)$ \\
\hline & $40^{\circ} \mathrm{N}$ & $1.3(1.0-1.8)$ & $0.52(0.29-1.34)$ \\
\hline & $45^{\circ} \mathrm{N}$ & $1.2(0.8-1.7)$ & $0.28(0.15-0.57)$ \\
\hline & $50^{\circ} \mathrm{N}$ & $6.7(1.1-20)$ & $1.4(0.22-4.9)$ \\
\hline \multirow{12}{*}{$\begin{array}{l}\mathrm{KH}- \\
17-4\end{array}$} & $120^{\circ} \mathrm{W}$ & $5.0(3.7-6.6)$ & $0.61(0.45-0.81)$ \\
\hline & $130^{\circ} \mathrm{W}$ & $3.5(2.1-5.4)$ & $0.57(0.33-0.90)$ \\
\hline & $140^{\circ} \mathrm{W}$ & $1.6(1.2-2.3)$ & $0.36(0.27-0.49)$ \\
\hline & $150^{\circ} \mathrm{W}$ & $3.2(1.5-6.4)$ & $0.46(0.20-0.90)$ \\
\hline & $160^{\circ} \mathrm{W}$ & $4.9(3.0-7.4)$ & $0.56(0.34-0.86)$ \\
\hline & $170^{\circ} \mathrm{W}$ & $5.3(2.9-9.5)$ & $0.58(0.32-1.05)$ \\
\hline & $179^{\circ} \mathrm{W}$ & $2.3(1.2-3.8)$ & $0.27(0.14-0.44)$ \\
\hline & $170^{\circ} \mathrm{E}$ & $2.3(1.2-4.3)$ & $0.24(0.13-0.49)$ \\
\hline & $160^{\circ} \mathrm{E}$ & $3.6(2.3-5.2)$ & $0.43(0.29-0.61)$ \\
\hline & $150^{\circ} \mathrm{E}$ & $8.3(4.3-13)$ & $0.85(0.46-1.38)$ \\
\hline & $140^{\circ} \mathrm{E}$ & $2.4(1.4-3.5)$ & $0.26(0.16-0.39)$ \\
\hline & $137^{\circ} \mathrm{E}$ & $1.7(1.2-2.3)$ & $0.18(0.12-0.26)$ \\
\hline
\end{tabular}

turbulence is elevated but not associated with the high $D_{\text {tide }}$, the wind is strong at $10^{\circ} \mathrm{N}$ and the equator (during cruise KH-13-7 in austral summer; Fig. 8c), where the mixed layer developed close to $100 \mathrm{~m}$ (Fig. 8c). In other areas, the level of $E_{\text {wind }}$ is not apparently linked to the turbulence level.

As seen in Fig. 3, a shallow permanent pycnocline appeared just below the surface mixed layer in the equatorial areas. This resulted in a clear latitudinal pattern of $\overline{\left\langle N^{2}\right\rangle}$, highest in the equatorial areas and showing a decreasing trend with latitude (Fig. 8e, f). There was a significant positive relationship between $\overline{\left\langle N^{2}\right\rangle}$ and $\overline{\langle\varepsilon\rangle}(r=0.60, p=0.00$, without the data at the equator showing the exceptionally strong mixing), while the relationship between $\overline{\left\langle N^{2}\right\rangle}$ and $\overline{\left\langle K_{\rho}\right\rangle}$ was not significant $(r=-0.06, p=0.76$, without the data at the equator).

The shear-to-strain ratio $R$ estimated for the $500-\mathrm{m}$ bin below the mixed layer showed a dome-shaped pattern with respect to latitude along $170^{\circ} \mathrm{W}$ (Fig. 9a) section and an increasing trend from west to east along the subtropical North Pacific section (Fig. 9b). Although the confidence intervals are wide (error bars in Fig. 9 are 5-95\% range), significant differences (no overlapping between 2.5-97.5\%, not shown in the figure) are observed between those in $15-25^{\circ} \mathrm{S}$ (high) and $30-40^{\circ} \mathrm{S}$ (low), and $15-25^{\circ} \mathrm{N}, 35^{\circ} \mathrm{N}$ (high) and $5-10^{\circ} \mathrm{N}, 45-50^{\circ} \mathrm{N}$ (low). The meridional and zonal distributions of $R$ have significant positive relationships with that of $D_{\text {tide }}$ (Fig. 8a; log-log linear correlation, $r=0.53, p=0.02$ ) and $E_{\text {wind }}$ (Fig. 8d; log-log-linear correlation, $r=0.79, p=0.00)$, respectively. However, neither $R-E_{\text {wind }}$ relationship along the meridional section and $R-D_{\text {tide }}$ relationship along the zonal section shows significant linear relationship (log-log-linear correlation, $r=-0.00, p=0.99$ and $r=-0.43, p=0.18$, in Fig. 8b, c, respectively). The $R$ distributions themselves show no correspondence with the stations of the strong turbulence (solid symbols).

\section{Discussion and conclusions}

Various observations have suggested that the background vertical eddy diffusivity is $O\left(10^{-5}\right) \mathrm{m}^{2} \mathrm{~s}^{-1}$ (Gregg 1987; Ledwell et al. 1993; Lewis et al. 1986). Our estimates of $\overline{\left\langle K_{\rho}\right\rangle}$ at the base-level stations were significantly smaller at $0.14-0.47 \times 10^{-5} \mathrm{~m}^{2} \mathrm{~s}^{-1}$, except for one station (Fig. $7 \mathrm{c}, \mathrm{d}$ and Table 2). We assume that our estimates are relatively low primarily because our observations were conducted only during summer when atmospheric conditions are calm (Alford 2003; Inoue et al. 2017) and subsurface stratification is developed. Whalen et al. (2018) showed that diffusivity is significantly increased from summer to winter, especially in areas with high eddy kinetic energy, where the ratio may be $2-3$ at the main pycnocline $(250-2000 \mathrm{~m})$. A seasonal difference is also indicated by observations in the eastern subtropical South Pacific. Fernandez-Castro et al. (2014) and Bouruet-Aubertot et al. (2018) made observations during April-May (30-300 m) and February-April (100-500 m), yielding average diffusivities of 3.0 and $0.45 \times 10^{-5} \mathrm{~m}^{2} \mathrm{~s}^{-1}$ (ratio of 6.7), respectively. Another possible explanation is the difference in the depth of layers. While we focused on the upper part of the pycnocline where nutrient transport is critical for the production, some studies on the mixing in the pycnocline used the data of slightly deeper layers; e.g., the experiment by Ledwell et al. (1993) injected the tracer into $310 \mathrm{~m}$ depth. The stronger stratification in the subsurface 
Fig. 7 Distributions of mean turbulent energy dissipation rate (a and $\mathbf{b}$ ) and mean vertical eddy diffusivity (c and d) averaged over the subsurface pycnocline. Error bars indicate 95\% confidence intervals. The thick dashed line shows the upper $25 \%$ level of $\varepsilon$; stations with $\langle\varepsilon\rangle$ elevated above this level are shown with solid symbols
Fig. 8 Distributions of total dissipation rate caused by the internal tide $D_{\text {tide }}$ according to the model of de Lavergne (2019) (a and b), turbulent energy production by the wind $E_{\text {wind }}$ calculated from the second Modern-Era Retrospective analysis for Research and Applications (MERRA2; Gelaro et al. 2017) (c and d) and ensemble and vertical average of stratification $\overline{\left\langle N^{2}\right\rangle}$ (e and f). Solid symbols indicate elevated turbulence as shown in Fig. 7
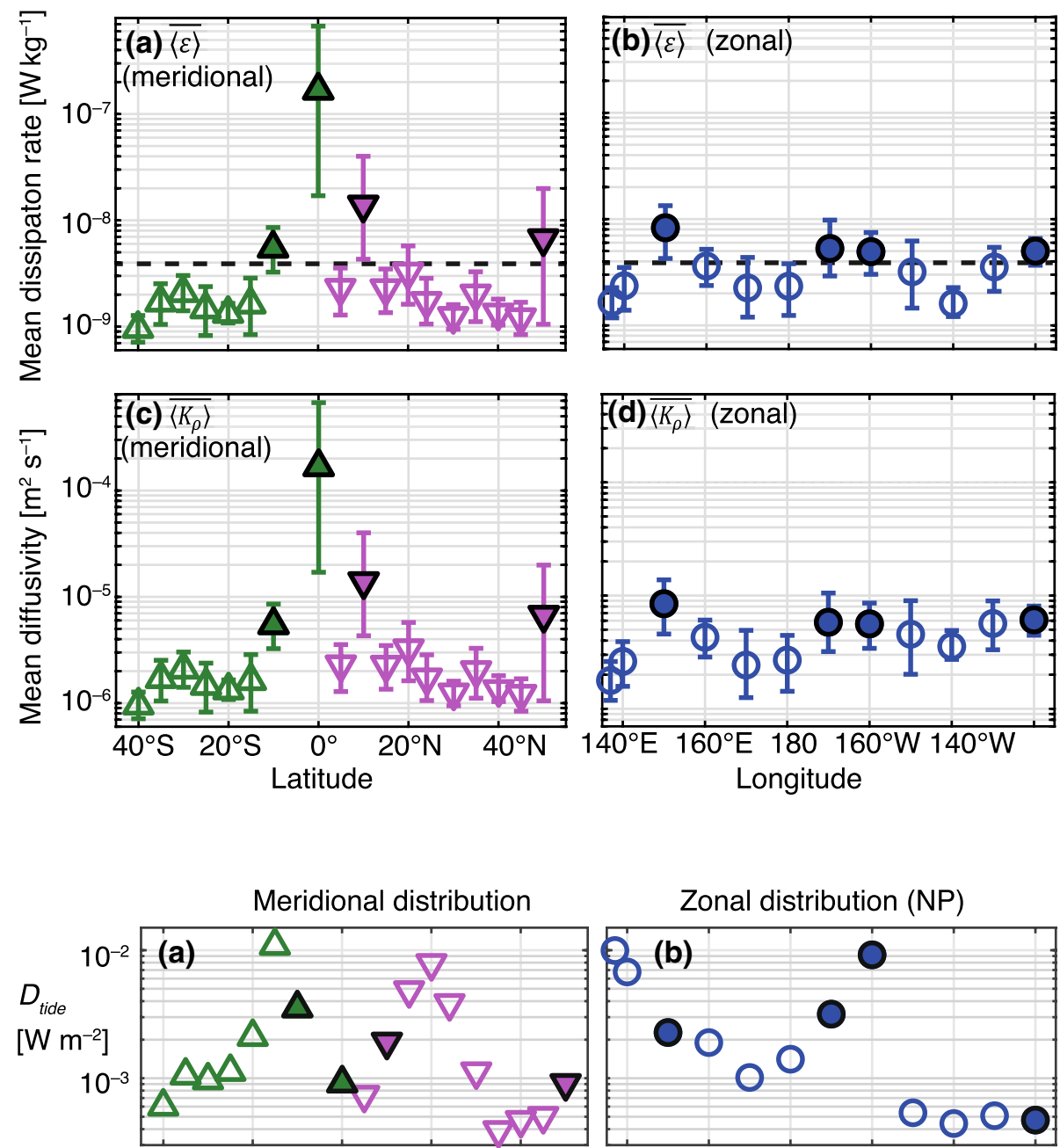

Zonal distribution (NP)
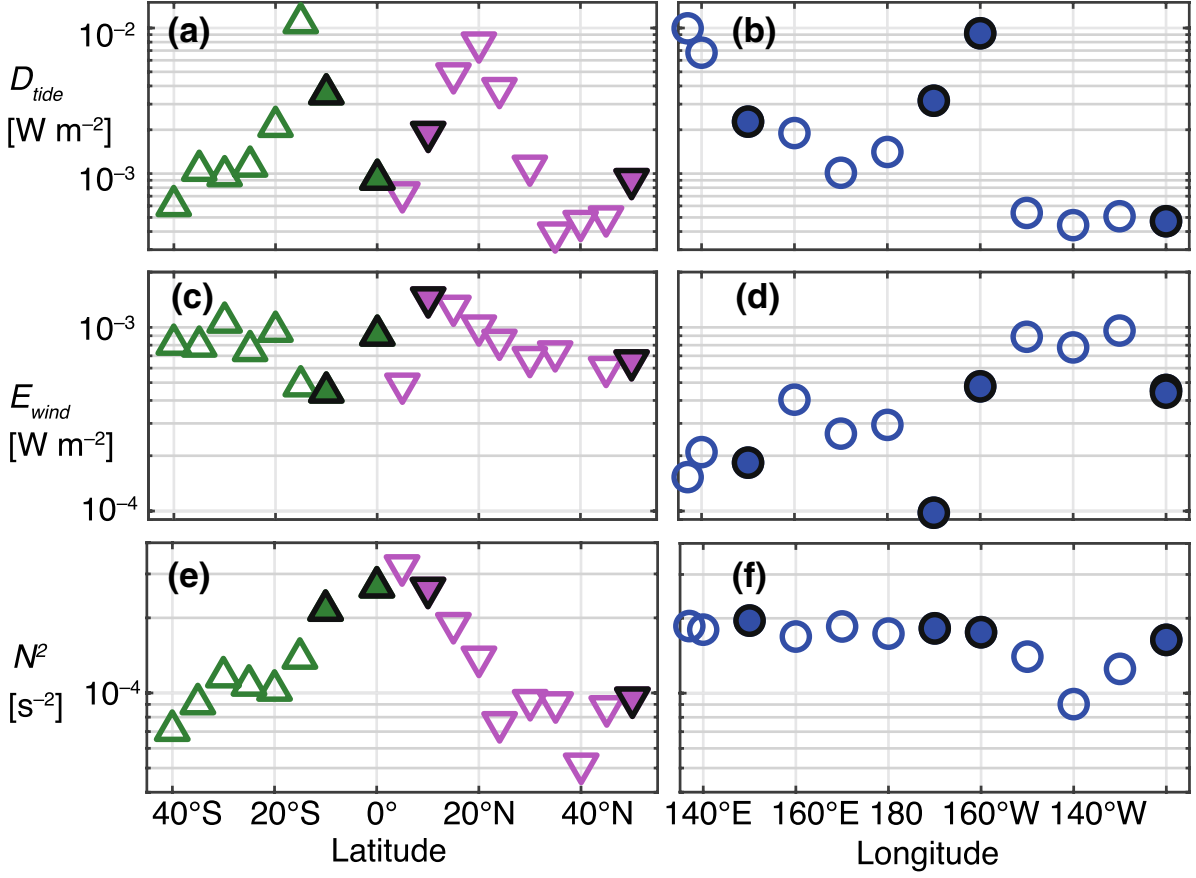

layers would cause the lower estimate of the diffusivity even if the energy dissipation rates were at a similar level.

At the equator, the layer we focused on was well below the surface mixing layer, likely corresponding to the upper core layer of the EUC, where diurnal variability is weak (Inoue et al. 2012). Previous studies have suggested that the shear of the EUC enhances turbulence (Inoue et al. 2012;
Fernández-Castro et al. 2014). However, as our observations are limited in number ( 3 profiles) and did not penetrate the core of the EUC, we can neither determine the diffusivity level nor identify the underlying mechanisms at the equator.

While our observations showed elevated turbulence around prominent topography, they were made in the subsurface pycnocline above $300 \mathrm{~m}$ at stations with seafloor 
Fig. 9 Shear-to-strain ratio $R$ calculated for the pycnocline below the mixed layer (mixed layer $+10 \mathrm{~m}-$ mixed layer $+510 \mathrm{~m}$ ). Error bars indicate $90 \%$ confidence intervals. Solid symbols indicate elevated turbulence as shown in Fig. 7

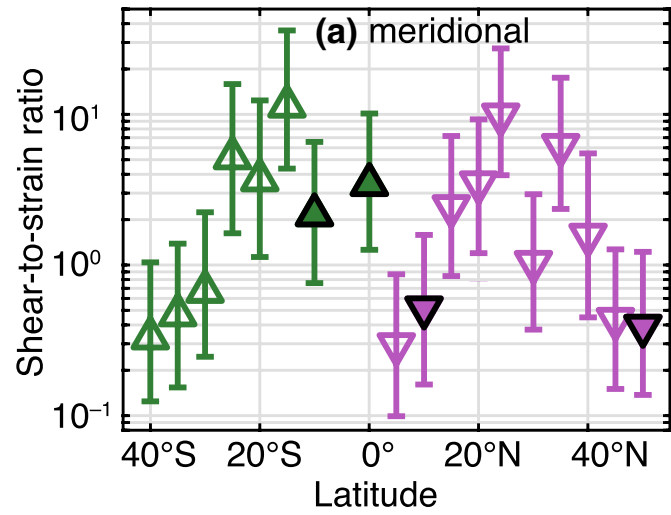

depth mostly greater than $3000 \mathrm{~m}$. Therefore, the elevation is unlikely to be attributable to the direct breaking of internal waves (St Laurent et al. 2002), but to the interactions of internal waves either generated, reflected, or modulated by the topography. The level of diffusivity near the Hawaiian Ridge $\left(160^{\circ} \mathrm{W}\right)$ is consistent with previous studies, in that it was one order of magnitude smaller than that on the ridge but still significantly higher than the background level (Fig. 7d; Klymak et al. 2006; Rudnick et al. 2003). The enhancement of the vertical mixing at $21^{\circ} 30^{\prime} \mathrm{N}, 170^{\circ} \mathrm{W}$ and $23^{\circ} \mathrm{N}, 150^{\circ} \mathrm{E}$ (Figs. 7 and 8) is likely related to the internal tide generated by the Mid-Pacific Seamounts and Marcus-Wake Seamount Group (Fig. 1). We assume that the overall effects of these topographic features have significant impacts on the vertical heat and material budget of the subsurface pycnocline in the open Pacific. However, the vertical diffusivity is not always elevated in areas with high $D_{\text {tide }}$, such as those around $15^{\circ} \mathrm{S}$ and $15-24^{\circ} \mathrm{N}$ along $170^{\circ} \mathrm{W}$, and 137 and $140^{\circ} \mathrm{E}$ along $23^{\circ} \mathrm{N}$ (Figs. 7, 8). One explanation for this apparent discrepancy is that less internal wave energy penetrates into the upper layer from the bottom. Patches of elevated turbulence are mainly distributed in the sharp pycnocline, and the pycnocline at some stations without enhanced turbulence, such as those at $137^{\circ} \mathrm{E}, 15^{\circ} \mathrm{S}$ and $20^{\circ} \mathrm{N}$, was relatively deep. This assumption is consistent with the positive relationship between $\overline{\left\langle N^{2}\right\rangle}$ and $\overline{\langle\varepsilon\rangle}$.

If the fine-scale variances are dominated by linear internal waves with a single frequency, the shear-to-strain ratio indicates the frequency of the waves: high for near-inertial waves and low (close to 1) for higher frequency waves such as semidiurnal internal waves in the low- and mid-latitudes (e.g., Chinn et al. 2016; Kunze et al. 2006). Since our estimates of $R$ fell below 1 in some areas, the above assumption on the frequency content does not hold. Nevertheless, the geographic pattern of $R$, dome shape with respect to latitude (Fig. 9a) and the increasing trend from west to east (Fig. 9b) suggests that the forcing and/or background conditions formed some kind of regimes of the fine-scale variability. Although the significant linear relationship between
$R$ and $E_{\text {wind }}$ along the zonal section suggests the sensitivity of $R$ to the near-inertial internal waves in the middle of the North Pacific subtropical gyre, the suggestion does not hold for the meridional section along $170^{\circ} \mathrm{W}$. Moreover, the positive relationship between $R$ and $D_{\text {tide }}$ along the meridional section is opposite to the expectation that increasing internal tide energy lowers the $R$ value. Because the shear-to-strain ratio is under the complex influences of internal tides and wind variability (Chinn et al. 2016) and also latitude (e.g., MacKinnon et al. 2013) and our focus is the subsurface pycnocline just below the surface mixed layer, clarification of the underlying mechanisms needs further accumulation of evidences.

In the present study, we have measured the geographical variability of the vertical eddy diffusivity in the subsurface pycnocline. The diffusivity levels and geographical distributions presented in this study improve estimations of the material transport into oligotrophic euphotic layers and will thus contribute to better understanding biogeochemical cycles. As for the other sources of the nitrogen for the new production, the role of biological nitrogen fixation has increasingly been highlighted (e.g., Horii et al. 2018). An evaluation of the vertical turbulent nutrient transport from the lower layer will be conducted in a future study, which will refine the definition of ocean biogeography based on the source type of the nitrogen for the new production.

Acknowledgments This study was supported by JSPS Kakenhi Grant Numbers JP24121002 and JP18H04912. The observations were conducted under the cooperative research operation of the R/V Hakuho Maru. The authors thank the captain, crew, and onboard scientists for their help in microstructure measurements, and two anonymous reviewers for their valuable comments.

Open Access This article is licensed under a Creative Commons Attribution 4.0 International License, which permits use, sharing, adaptation, distribution and reproduction in any medium or format, as long as you give appropriate credit to the original author(s) and the source, provide a link to the Creative Commons licence, and indicate if changes were made. The images or other third party material in this article are included in the article's Creative Commons licence, unless indicated 
otherwise in a credit line to the material. If material is not included in the article's Creative Commons licence and your intended use is not permitted by statutory regulation or exceeds the permitted use, you will need to obtain permission directly from the copyright holder. To view a copy of this licence, visit http://creativecommons.org/licenses/by/4.0/.

\section{References}

Alford MH (2003) Improved global maps and 54-year history of windwork on ocean inertial motions. Geophys Res Lett. https://doi. org/10.1029/2002g1016614

Baker MA, Gibson CH (1987) Sampling turbulence in the stratified ocean: statistical consequences of strong intermittency. J Phys Oceanogr 17(10):1817-1836. https://doi.org/10.1175/15200485(1987)017\%3c1817:Stitso\%3e2.0.Co;2

Bouruet-Aubertot $\mathrm{P}$ et al (2018) Longitudinal contrast in turbulence along a similar to 19 degrees $\mathrm{S}$ section in the Pacific and its consequences for biogeochemical fluxes. Biogeosciences 15(24):7485-7504. https ://doi.org/10.5194/bg-15-7485-2018

Chinn BS, Girton JB, Alford MH (2016) The impact of observed variations in the shear-to-strain ratio of internal waves on inferred turbulent diffusivities. J Phys Oceanogr 46(11):3299-3320. https://doi. org/10.1175/jpo-d-15-0161.1

Cullen JJ (2015) Subsurface chlorophyll maximum layers: enduring enigma or mystery solved? Ann Rev Marine Sci 7(7):207-239. https ://doi.org/10.1146/annurev-marine-010213-135111

D'Asaro E, Lee C, Rainville L, Harcourt R, Thomas L (2011) Enhanced turbulence and energy dissipation at ocean fronts. Science 332:318-322

de Lavergne C, Falahat S, Madec G, Roquet F, Nycander J, Vic C (2019) Toward global maps of internal tide energy sinks. Ocean Model 137:52-75. https://doi.org/10.1016/j.ocemod.2019.03.010

Fer I, Peterson AK, Ullgren JE (2014) Microstructure measurements from an underwater glider in the turbulent faroe bank channel overflow. J Atmosp Oceanic Technol 31(5):1128-1150. https://doi.org/10.1175/ jtech-d-13-00221.1

Fernandez-Castro B, Mourino-Carballido B, Benitez-Barrios VM, Choucino P, Fraile-Nuez E, Grana R, Piedeleu M, Rodriguez-Santana A (2014) Microstructure turbulence and diffusivity parameterization in the tropical and subtropical Atlantic, Pacific and Indian Oceans during the Malaspina 2010 expedition. Deep-Sea Res Part I-Oceanograph Res Papers 94:15-30. https://doi.org/10.1016/j. dsr.2014.08.006

Furuya K (1990) Subsurface chlorophyll maximum in the tropical and subtropical western Pacific-Ocean: vertical profiles of phytoplankton biomass and its relationship with chlorophyll-a and particulate organic-carbon. Mar Biol 107(3):529-539. https://doi.org/10.1007/ bf01313438

Gelaro R et al (2017) The modern-Era retrospective analysis for research and applications, version 2 (MERRA-2). J Clim 30(14):5419-5454. https://doi.org/10.1175/JCLI-D-16-0758.1

Gregg MC (1987) Diapycnal mixing in the thermocline: a review. J Geophys Res. https://doi.org/10.1029/JC092iC05p05249

Gregg MC, Peters H, Wesson JC, Oakey NS, Shay TJ (1985) Intensive measurements of turbulence and shear in the equatorial undercurrent. Nature 318(6042):140-144. https://doi.org/10.1038/318140a0

Hanawa K, Talley LD (2001) Mode waters. In: Siedler G, Church J, Gould J (eds) International Geophysics. Academic Press, London, pp 373-386

Horii S, Takahashi K, Shiozaki T, Hashihama F, Furuya K (2018) Stable isotopic evidence for the differential contribution of diazotrophs to the epipelagic grazing food chain in the mid-Pacific Ocean. Glob Ecol Biogeogr 27(12):1467-1480. https://doi.org/10.1111/ geb. 12823
Inoue R, Lien RC, Moum JN (2012) Modulation of equatorial turbulence by a tropical instability wave. J Geophys Res Oceans. https://doi. org/10.1029/2011jc007767

Inoue R, Watanabe M, Osafune S (2017) Wind-Induced Mixing in the North Pacific. J Phys Oceanogr 47(7):1587-1603. https://doi. org/10.1175/jpo-d-16-0218.1

Kaneko H, Yasuda I, Komatsu K, Itoh S (2012) Observations of the structure of turbulent mixing across the Kuroshio. Geophys Res Lett 39:15. https://doi.org/10.1029/2012g1052419

Kaneko H, Yasuda I, Itoh S, Ito S-I (2020) Vertical turbulent nitrate flux from direct measurements in the western subarctic and subtropical gyres of the North Pacific. J Oceanography 10:120-130

Klymak JM, Moum JN, Nash JD, Kunze E, Girton JB, Carter GS, Lee CM, Sanford TB, Gregg MC (2006) An estimate of tidal energy lost to turbulence at the Hawaiian Ridge. J Phys Oceanogr 36(6):11481164. https://doi.org/10.1175/jpo2885.1

Kouketsu S (2018) Spatial distribution of diffusivity coefficients and the effects on water mass modification in the North Pacific. J Geophys Res-Oceans 123(6):4373-4387. https://doi.org/10.1029/2018jc0138 60

Kunze E, Firing E, Hummon JM, Chereskin TK, Thurnherr AM (2006) Global abyssal mixing inferred from lowered ADCP shear and CTD strain profiles. J Phys Oceanogr 36(8):1553-1576

Leaman KD, Sanford TB (1975) Vertical energy propagation of inertial waves - vector spectral analysis of velocity profiles. J Geophys Res 80(15):1975-1978

Ledwell JR, Watson AJ, Law CS (1993) Evidence for slow mixing across the pycnocline from an open-ocean tracer-release experiment. Nature 364(6439):701-703. https://doi.org/10.1038/364701a0

Levitus S (1983) Climatological atlas of the world ocean. Eos Trans AGU 64(49):962-963. https://doi.org/10.1029/EO064i049p00962-02

Lewis MR, Harrison WG, Oakey NS, Hebert D, Platt T (1986) Vertical nitrate fluxes in the oligotrophic ocean. Science 234(4778):870-873. https://doi.org/10.1126/science.234.4778.870

Liu ZY, Lian Q, Zhang FT, Wang L, Li MM, Bai XL, Wang JN, Wang $F$ (2017) Weak thermocline mixing in the north pacific low-latitude western boundary current system. Geophys Res Lett 44(20):10530-10539

Longhurst AR (2007) Ecological Geography of the Sea, Second, Edition. Academic Press, Burlington, MA

MacKinnon JA, Alford MH, Pinkel R, Klymak J, Zhao Z (2013) The latitudinal dependence of shear and mixing in the Pacific transiting the critical latitude for PSI. J Phys Oceanogr 43(1):3-16. https://doi. org/10.1175/jpo-d-11-0107.1

Mori K, Uehara K, Kameda T, Kakehi S (2008) Direct measurements of dissipation rate of turbulent kinetic energy of North Pacific subtropical mode water. Geophys Res Lett 35:5. https://doi. org/10.1029/2007gl032867

Moum JN, Osborn TR (1986) Mixing in the main thermocline. J Phys Oceanogr 16(7):1250-1259. https://doi.org/10.1175/15200485(1986)016\%3c1250:Mitmt\%3e2.0.Co;2

Nagai T, Tandon A, Yamazaki H, Doubell MJ (2009) Evidence of enhanced turbulent dissipation in the frontogenetic Kuroshio Front thermocline. Geophys Res Lett 36:12. https://doi. org/10.1029/2009GL038832

Nagai T, Tandon A, Yamazaki H, Doubell MJ, Gallager S (2012) Direct observations of microscale turbulence and thermohaline structure in the Kuroshio Front. J Geophys Res Oceans. https://doi. org/10.1029/2011JC007228

Oka E, Qiu B (2011) Progress of North Pacific mode water research in the past decade. J Oceanogr 68(1):5-20. https://doi.org/10.1007/ s10872-011-0032-5

Osborn TR (1980) Estimates of the local rate of vertical diffusion from dissipation measurements. J Phys Oceanogr 10(1):83-89. https:// doi.org/10.1175/1520-0485(1980)010\%3c0083:Eotlro\%3e2.0.Co;2 
Rudnick DL et al (2003) From tides to mixing along the Hawaiian ridge. Science 301(5631):355-357. https://doi.org/10.1126/science.10858 37

Smith WHF, Sandwell DT (1997) Global sea floor topography from satellite altimetry and ship depth soundings. Science 277(5334):19561962. https://doi.org/10.1126/science.277.5334.1956

St Laurent LC, Simmons HL, Jayne SR (2002) Estimating tidally driven mixing in the deep ocean. Geophys Res Lett 29(23):21-24. https:// doi.org/10.1029/2002gl015633

Talley LD, Pickard GL, Emery WJ, Swift JH (2011) Descriptive physical oceanography. Academic Press, Cambridge

Thurnherr AM (2010) A practical assessment of the errors associated with full-depth LADCP profiles obtained using teledyne rdi workhorse acoustic doppler current profilers. J Atmosph Oceanic Technol 27(7):1215-1227. https://doi.org/10.1175/2010jtecho708.1

Waterhouse AF et al (2014) Global patterns of diapycnal mixing from measurements of the turbulent dissipation rate. J Phys Oceanogr 44(7):1854-1872. https://doi.org/10.1175/Jpo-D-13-0104.1

Whalen CB, MacKinnon JA, Talley LD, Waterhouse AF (2015) Estimating the mean diapycnal mixing using a finescale strain parameterization. J Phys Oceanogr 45(4):1174-1188. https://doi.org/10.1175/ jpo-d-14-0167.1

Whalen CB, MacKinnon JA, Talley LD (2018) Large-scale impacts of the mesoscale environment on mixing from wind-driven internal waves. Nature Geosci 11(11):842. https://doi.org/10.1038/s4156 1-018-0213-6 